\title{
Ethylene and Carbon Dioxide Production in Detached Fruit of Selected Pepper Cultivars
}

\author{
Lucia Villavicencio, ${ }^{1}$ Sylvia M. Blankenship, ${ }^{2}$ Douglas C. Sanders, ${ }^{2}$ William H. Swallow ${ }^{3}$ \\ Department of Horticultural Science, North Carolina State University, Raleigh, NC 27695-7609
}

\begin{abstract}
AdDITIONAL INDEX wORDS. respiration, maturation, climacteric, Capsicum annuum, Capsicum chinense, Capsicum frutescens, ripening

Aвstract. Bell peppers (Capsicum annuum L.) are classified as nonclimacteric fruits while some hot peppers have been reported as climacteric. Responses of peppers to exogenously applied ethylene-releasing compounds suggest ethylene involvement in the ripening process. Ethylene production and respiration rates in 13 cultivars of pepper: 'Camelot', 'Cherry Bomb', 'Chiltepin', ‘Cubanelle', 'Banana Supreme', 'Habanero', 'Hungarian Wax', ‘Mesilla', 'Mitla', ‘Savory', 'Sure Fire’, 'Tabasco', and 'King Arthur' were studied under greenhouse and field conditions. Fruit from each cultivar were harvested at different maturity stages determined by color, ranging from mature-green to full red-ripe. Carbon dioxide and ethylene production were measured by gas chromatography. Both variables were significantly different among maturity stages for all cultivars. Respiration rates were between 16.5 and $440.3 \mathrm{mg} \cdot \mathrm{kg}^{-1} \cdot \mathrm{h}^{-1} \mathrm{CO}_{2}$. Ethylene production ranged from 0.002 to 1.1 $\mu \mathrm{L} \cdot \mathrm{kg}^{-1} \cdot \mathrm{h}^{-1}$. Two patterns of $\mathrm{CO}_{2}$ production were identified: higher $\mathrm{CO}_{2}$ production for mature-green fruit with successive decreases for the rest of the maturity stages or lower respiration rates for mature-green fruit with an increase in $\mathrm{CO}_{2}$ production either when fruit were changing color or once fruit were almost totally red. A rise in $\mathrm{CO}_{2}$ production was present for most cultivars. Ethylene evolution increased significantly at maturity or before maturity in all cultivars except 'Cubanelle' and 'Hungarian Wax'. Respiration rates and ethylene production were significantly different among cultivars at the mature-green and red stages.
\end{abstract}

Consumption and production of peppers (Capsicum L. spp.) in the United States has increased (Andrews, 1995). This trend is likely to continue, supported by introduction of new cultivars (Smith et al., 1987). Several fresh-market pepper types are grown: bell, chili, jalapeno, cayenne, and cherry peppers (Smith etal., 1987). 'Tabasco' peppers (Capsicum frutescens L.) are also grown and used to make hot sauce (Lang, 1989). Bell peppers (Capsicum annuum var. annuum) are usually harvested at the horticulturally mature-green stage. Fruit at this stage may or may not undergo changes in color depending on the age of the tissues. For some types, development of color is essential in obtaining a high quality product and this process is usually associated with fruit ripening (Pratt and Goeschl, 1969).

Peppers have been classified as nonclimacteric fruit (Biles et al., 1993; Lurie et al., 1986; Lurie and Klein, 1989; Salveit, 1977). The hot pepper 'Chooraehong' is reported as climacteric (Gross et al., 1986). Other cultivars of hot peppers such as 'Changjiao' and the New Mexico type peppers have been reported as nonclimacteric (Biles et al. 1993, Lu et al. 1990). By definition, in nonclimacteric fruit the increase in respiration and ethylene production during ripening is absent. Although it does not occur spontaneously, in some nonclimacteric fruit, a climacteric can be induced by ethylene treatment (Biale 1948). Application of ethylene-releasing products to bell pepper plants (Osterli et al., 1975), chili or pimiento pepper (Lockwood and Vine 1972; Sims et al., 1970), jalapeno (Dainello

Received for publication 13 Oct. 1998. Accepted for publication 15 Apr. 1999 This research was funded in part by the North Carolina Agricultural Research Service (NCARS) Raleigh, NC 27695-7643, the U.S. Dept. of Agriculture (USDA), Consejo Nacional de Investigacious Cientificas y Tecnologicas (CONICIT) and Universidad del Zulia, Maracaibo,Venezuela. Mention of a trademark or proprietary product does not constitute a guarantee or warranty of the product by either the NCARS or the USDA and does not imply its approval to the exclusion of other products that may also be suitable. From a thesis submitted by the senior author in partial fulfillment of the requirements for the MS degree. The cost of publishing this paper was defrayed in part by the payment of page charges. Under postal regulations, this paper therefore must be hereby marked advertisement solely to indicate this fact.

'Graduate student.

${ }^{2}$ Professor

${ }^{3}$ Professor, Department of Statistics. and Heineman, 1980) and 'Tabasco' pepper(Conrad and Sundstrom, 1987) increased color development of fruit. These results suggest involvement of ethylene in induction of ripening in peppers. Ethylene production in red peppers has been reported to be higher than at any other maturity stage, but this amount was not enough to induce autocatalytic ethylene production (Biles et al., 1993; Lurie et al., 1986). Even where concentrations of ethylene capable of inducing ripening in peppers were observed, the respiratory rise coincident with the onset of ripening was absent (Biles et al. 1993).

There has been some argument whether or not the respiratory rise observed in climacteric fruit is an intrinsic part of the ripening process of such fruit. In attached tomato fruit (Lycopersicon esculentum Mill.), this rise was absent during ripening. Results suggested that the so called climacteric rise in $\mathrm{CO}_{2}$ could be an artifact derived from using harvested fruit, and it was proposed that this feature should not be considered in classifying fruit (Salveit, 1993). However, it has also been argued that changes in respiration are difficult to detect in attached fruit because of other simultaneously occurring changes (Knee, 1995). Studies evaluating ethylene and $\mathrm{CO}_{2}$ production in pepper types are limited (Biles et al., 1993; Gross et al., 1986; Salveit, 1977). Therefore, our objective was to measure ethylene production and respiration rates in detached fruit during maturation of selected cultivars of pepper in an effort to clarify the ripening characteristics of peppers and to improve postharvest handling information.

\section{Materials and Methods}

Plant Material. Seed of 13 cultivars of pepper, which included three species, two varieties, and eight types, were obtained from commercial sources (Table 1). Experiments were conducted in the Horticultural Science Greenhouse in Raleigh and in the field at the Horticultural Crops Research Station, Clinton, N.C.

Greenhouse experiment. Plants of 'Camelot', 'Cubanelle' and 'Hungarian Wax' were grown in the greenhouse. Seeds were sown in a 1 peat : 1 vermiculite medium (v/v) on 12 Dec. 1996. After developing two pairs of true leaves, seedlings were transplanted to 
Table 1. Species, cultivars, and types of peppers.

\begin{tabular}{|c|c|}
\hline Species and cultivar & Type \\
\hline Capsicum annuum var. annuum L. 'Camelot' & Bell \\
\hline Capsicum anпиum var. annиum L. 'King Arthur' & Bell \\
\hline Capsicum annuиm var. annuиm L. 'Cubanelle' & Cuban \\
\hline Capsicum annuum var. annuum L. 'Mesilla' & Cayenne \\
\hline Capsicum annuиm var. anпиит L. 'Mitla' & Jalapeno \\
\hline Capsicum annиum var. annиum L. 'Surefire' & Thai \\
\hline Capsicum annuиm var. annuum L. 'Hungarian Wax' & Hot banana \\
\hline Capsicum annuum var. glabrisculum L. 'Chiltepin' & Pequin \\
\hline \multicolumn{2}{|l|}{ Capsicum frutescens L. 'Tabasco' } \\
\hline \multicolumn{2}{|l|}{ Capsicum chinense Jacq. 'Habanero' } \\
\hline Capsicum chinense Jacq. 'Savory' & \\
\hline
\end{tabular}

$8933 \mathrm{~cm}^{3}$ pots and maintained under natural photoperiod and irradiance at days and nights of 24 and $21^{\circ} \mathrm{C}$. Plants were fertilized monthly with $250 \mathrm{~mL} \cdot \mathrm{L}^{-1}$ of a $20 \mathrm{~N}-4.5 \mathrm{P}-8.3 \mathrm{~K}$ water soluble fertilizer (Grace Sierra Horticultural Products, Milpitas, Calif.). Fruit were harvested between 8 Apr. 1997 and 1 July 1997 at several maturity stages determined visually by color ranging from mature-green to full red-ripe. The scale used was 1 = mature-green pepper (no presence of red color); $2=$ peppers just turning color (slight color change from yellow to red, depending on cultivar); 3 = fruit surface color change almost complete (from orange to red, depending on cultivar); 4 = light red; and $5=$ red ripe (dark red-ripe fruit). Initially, flowers were tagged and days from anthesis were to be the measures of fruit maturity. However, due to poor correlation between fruit color and days from anthesis, it was decided to use only color as a maturity indicator.

Field EXPERIMENT. 'King Arthur', 'Cherry Bomb', 'Mesilla', 'Mitla', 'Surefire', 'Banana Supreme', 'Savory', 'Habanero', 'Tabasco' and 'Chiltepin' were planted between 25 Apr. and 1 May 1997. The plots were drip fertigated and maintained according to standard commercial cultural practices. Plastic mulch was used. Fruit from each cultivar were harvested at maturity stages according to color as described previously. Harvests were done from 26 June through 21 Sept. 1997.

ETHYLENE AND $\mathrm{CO}_{2}$ MEASUREMENTS. In the greenhouse experiment, 15 fruit per cultivar were harvested and sealed in individual jars for a period of time appropriate for ethylene accumulation, ranging from 2.8 to $28.5 \mathrm{~h}$ (depending on cultivar). Sealing times were standard for each cultivar. Jar volume depended on cultivar, varying between $1950 \mathrm{~cm}^{3}$ for bell peppers to $22 \mathrm{~cm}^{3}$ for the smallest peppers. Ethylene and $\mathrm{CO}_{2}$ production were recorded at intervals (data not presented) and the concentration of both gases was increasing in a linear fashion. Jars were kept under cool-white fluorescent lamps at $27{ }^{\circ} \mathrm{C}$. Photosynthetically active radiation $(P A R)$ in the lab was $27.6 \mathrm{mmol} \cdot \mathrm{m}^{-2} \cdot \mathrm{s}^{-1}$ as measured at the bottom of the jar with a quantum radiometer-photometer (LI-185A; LICOR, Lincoln, Nebr.). Air samples were withdrawn from a jar through a rubber septum inserted in the lid. To determine ethylene production $\left(\mu \mathrm{L} \cdot \mathrm{kg}^{-1} \cdot \mathrm{h}^{-1}\right)$, a 1-mL air sample was injected into a gas chromatograph with an alumina column (series 1400, Varian Aerograph, Sugarland, Texas). Carbon dioxide production ( $\mathrm{mg} \cdot \mathrm{kg}^{-}$ ${ }^{1} \cdot \mathrm{h}^{-1}$ ) was determined in $1-\mathrm{mL}$ gas samples by using a gas partitioner (model 1200; Fisher Scientific Co., Pittsburgh, Pa.) equipped with a thermal conductivity detector. In the field experiment, 35 fruit per cultivar were harvested and sealed individually in jars for 4.7 to 26.4 $\mathrm{h}$ (depending on cultivar). Ethylene and $\mathrm{CO}_{2}$ production were determined as described above.
Statistical analysis. Data were subjected to analysis of variance using general linear model procedures (SAS, 1988). Differ-

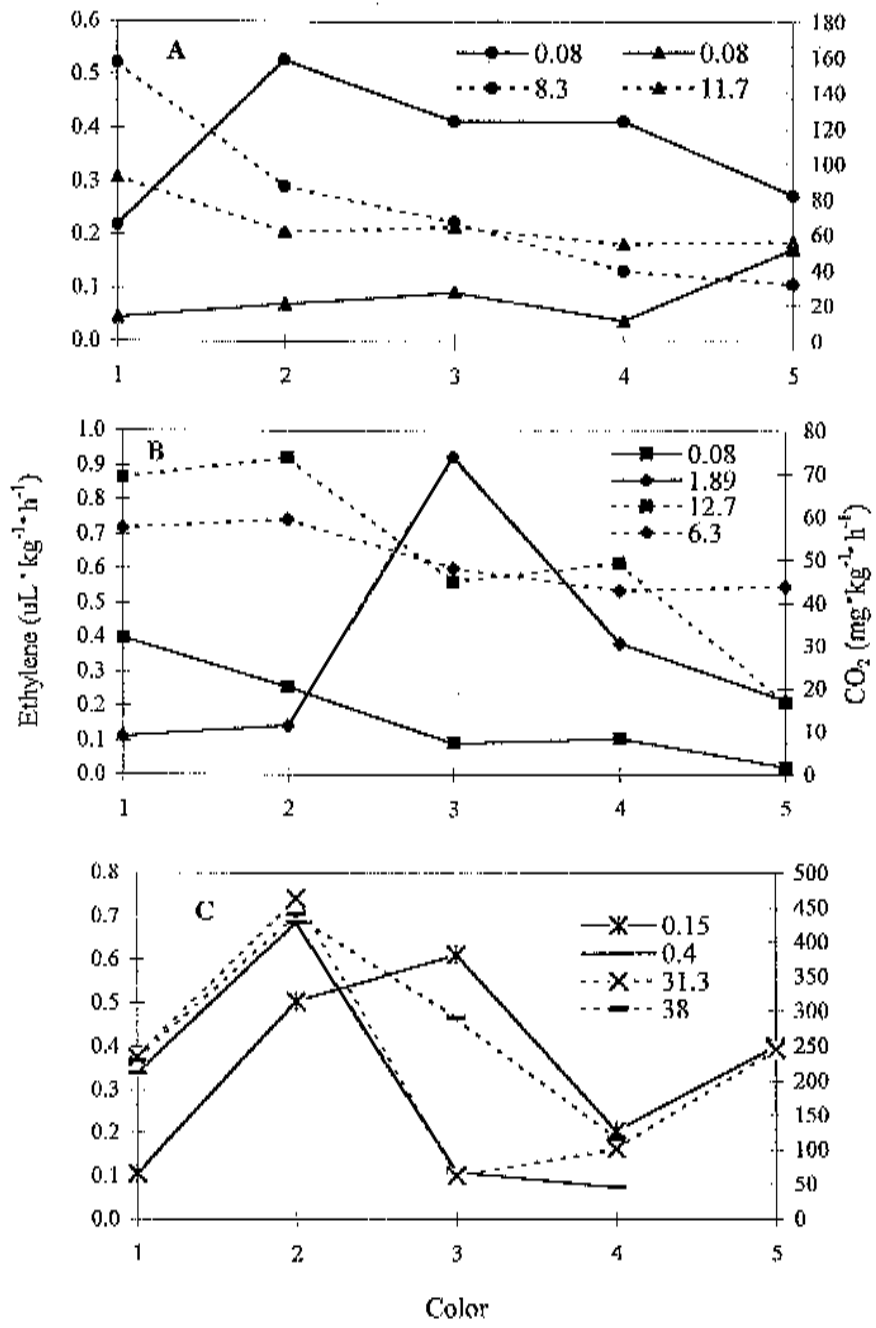

Fig. 1. Changes in ethylene (solid lines) and $\mathrm{CO}_{2}$ (broken lines) production in

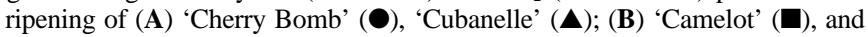
'King Arthur' ( $\bullet$; and $(\mathbf{C})$ 'Tabasco' $(\times)$, and 'Chiltepin' (-) peppers. Each data point represents the mean of 15 observations for 'Cubanelle' and 'Camelot', and the mean of 35 observations for the other cultivars. Color: $1=$ mature-green fruit; $2=$ peppers just turning color (part of the fruit surface was yellow to red, depending on cultivar); $3=$ fruit surface almost totally red or orange; $4=$ light red; and $5=$ dark red. Numbers next to the symbols represent LSD values, $P=0.05$. 

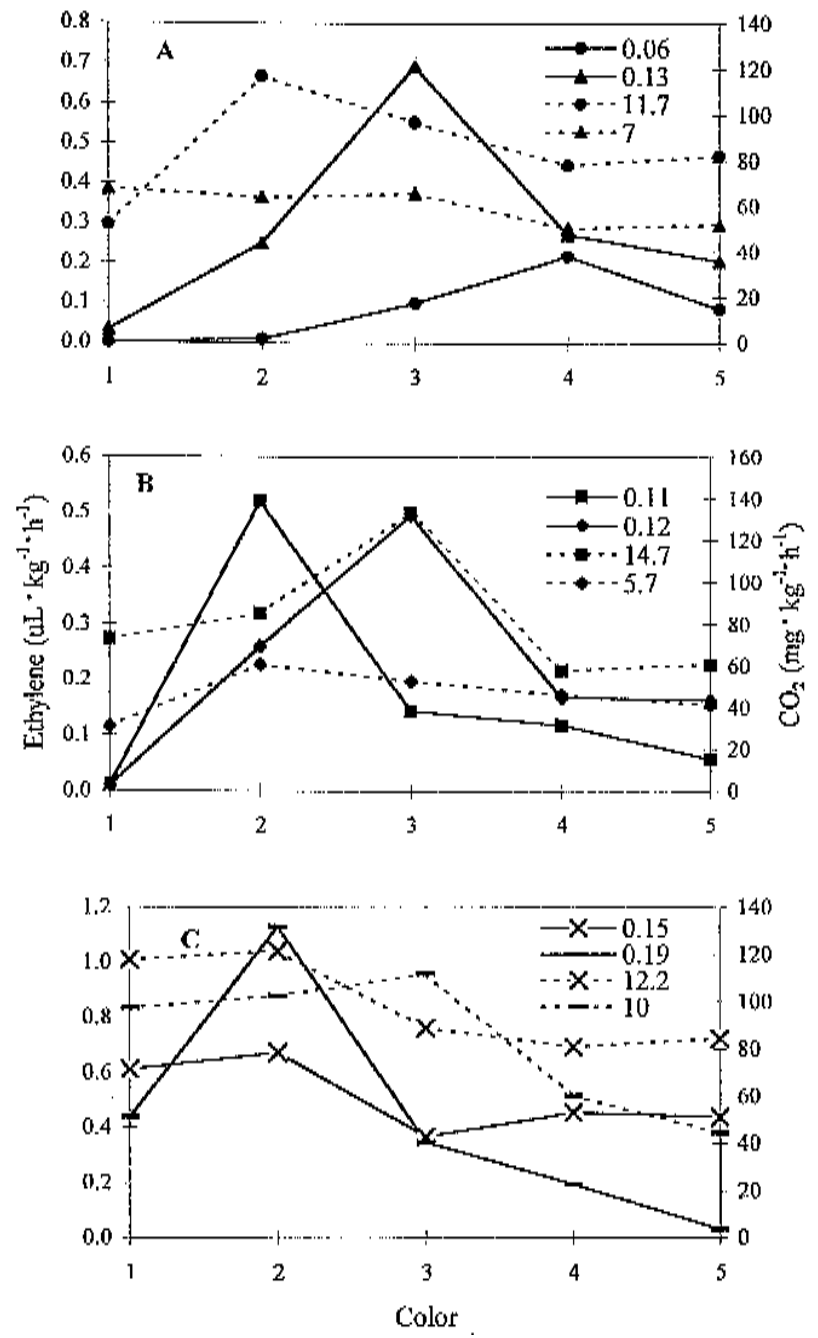

Fig. 2. Changes in ethylene (solid lines) and $\mathrm{CO}_{2}$ (broken lines) production in ripening of (A) 'Hungarian Wax' (-), and 'Banana Supreme' $(\mathbf{A})$; (B) 'Mesilla' $(\mathbf{\square})$, and 'Sure Fire' $(\bullet)$; and $(\mathbf{C})$ 'Habanero' $(\times)$, and 'Savory' (-) peppers. Each data point represents the mean of 15 observations for 'Hungarian Wax', and the mean of 35 observations for the other cultivars. Color: $1=$ mature-green fruit; 2 $=$ peppers just turning color (part of the fruit surface was yellow to red, depending on cultivar); 3 = fruit surface almost totally red or orange; $4=$ light red; and $5=$ dark red. Numbers next to the symbols represent LSD values, $P=0.05$.

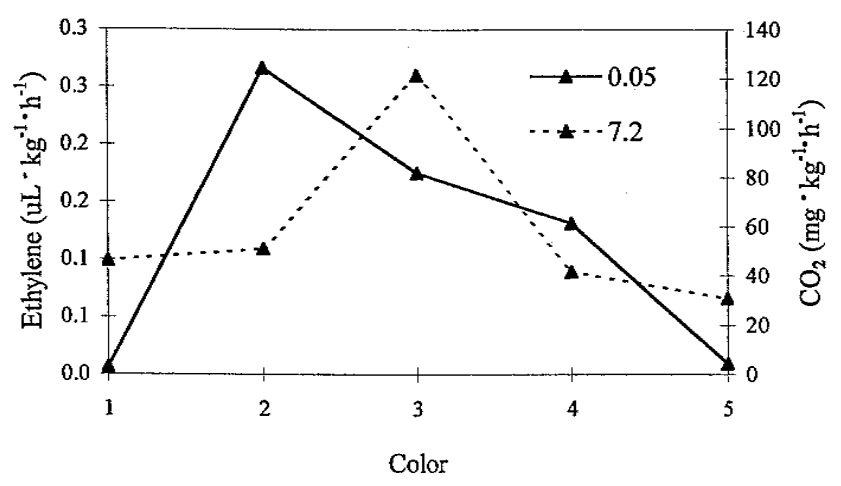

Fig. 3. Changes in ethylene (solid line) and $\mathrm{CO}_{2}$ (broken line) production in ripening 'Mitla' peppers. Each data point represents the mean of 35 observations. Colors: 1 = mature-green fruit; 2 = peppers just turning color (part of the fruit surface was yellow to red, depending on cultivar); $3=$ fruit surface almost totally red or orange; $4=$ light red; and $5=$ dark red. Numbers next to the symbols represent LSD values, $P=0.05$. ences among maturity stages (colors) were established for each cultivar and LSD values calculated at $P=0.05$.

\section{Results and Discussion}

Mature-green 'Cherry Bomb' peppers produced significantly higher amounts of $\mathrm{CO}_{2}$ than fruit at any other maturity stage. This production decreased in a uniform and significant manner in subsequent maturity stages, reaching the lowest value when fruit were red-ripe. No increase in respiration rate was observed at the time of color change. In general, young, immature tissues tend to have higher respiratory rates than older, more mature tissues (Kays, 1991).

In contrast, ethylene production in 'Cherry Bomb' showed a 2.4fold increase between mature-green fruit and fruit just turning color (Fig. 1A). Subsequent maturity stages showed declining rates of ethylene production. Large increases in ethylene production usually precede or coincide with ripening and the respiratory climacteric. It has been proposed that ethylene increase causes induction of the rise in $\mathrm{CO}_{2}$ (Kays, 1991) and the ripening process (Pratt and Goeschl, 1969). Nonclimacteric fruit do not show increases in respiration or ethylene production during ripening nor extensive ripening after detachment from the plant; and their patterns of respiration will change slowly after harvest (Salveit, 1993). 'Cherry Bomb’ peppers exhibited the typical respiratory pattern of nonclimacteric fruit. Ethylene production increased slightly, but significantly, when fruit were turning color. The absence of a peak in $\mathrm{CO}_{2}$ production and increase up to 5-fold in ethylene production coincident with ripening in hot peppers have been previously reported (Biles, 1993).

Carbon dioxide production was relatively high in 'Cubanelle' (Fig. 1A) and 'Camelot' (Fig. 1B) green fruit, decreasing in later stages. Ethylene production for 'Cubanelle' was consistently low through the period of study, while in 'Camelot', it was higher in green fruit than in later stages of fruit ripening. Neither respiration rate nor ethylene production increased at the time of color change. 'Camelot', which is a bell pepper, showed higher respiration rates and ethylene production than those reported for another cultivar of green bell pepper (Lurie et al., 1986). However, the rates of ethylene production observed in green and mature fruit were similar to (Harpster et al., 1996; Lurie et al., 1986) and lower than previously reported values for bell peppers (Pretel et al., 1995). The pattern of $\mathrm{CO}_{2}$ production was also similar to that reported for 'California' peppers, where no significant rise in $\mathrm{CO}_{2}$ production was observed in fruit changing color (Pretel et al., 1995). The cultivars of bell peppers used in this study were not uniform in ethylene and $\mathrm{CO}_{2}$ production. 'King Arthur' (Fig. 1B) had a slight, but statistically insignificant increase, in $\mathrm{CO}_{2}$ production of fruit changing color compared to that of green fruit. However, $\mathrm{CO}_{2}$ production of green and color turning fruit was significantly higher than $\mathrm{CO}_{2}$ production at any other maturity stage. A peak in ethylene production was observed in fruit almost totally red. This increase was significantly higher than the ethylene detected for the rest of the maturity stages and it was not coincident with the peak in $\mathrm{CO}_{2}$.

'Tabasco' and 'Chiltepin' peppers produced the highest amount of $\mathrm{CO}_{2}$ (463.8 and $440.3 \mathrm{mg} \cdot \mathrm{kg}^{-1} \cdot \mathrm{h}^{-1}$ respectively), of all the peppers studied (Fig. 1C). Patterns of ethylene and $\mathrm{CO}_{2}$ production in 'Chiltepin' were similar, with a peak when fruit were turning color and amounts decreasing to reach the minimum point when fruit were light red. The increase in ethylene was 2-fold higher in fruit turning color than in green fruit. Ethylene and $\mathrm{CO}_{2}$ production decreased gradually after the fruit changed colors and reached a minimum value $\left(0.073 \mu \mathrm{L} \cdot \mathrm{kg}^{-1} \cdot \mathrm{h}^{-1}\right.$ and $115.9 \mathrm{mg} \cdot \mathrm{kg}^{-1} \cdot \mathrm{h}^{-1}$, respectively) when the fruit were light red. 
Ethylene production of 'Tabasco' increased when fruit were turning color and decreased in light red and red fruit (Fig. 1C). Maximum ethylene production was almost 6-fold higher than that of green fruit. Carbon dioxide production followed a similar pattern to that of ethylene production, but the maximum amount preceded the peak in ethylene production and it was observed when fruit were just turning color. Increases in $\mathrm{CO}_{2}$ and ethylene production at dark red stages could be due to chemical changes occurring in early senescing tissues. Leaves have shown an increase in respiration during the early stages of senescence (Kays, 1991).

Respiration rates for 'Tabasco' and 'Chiltepin' were higher than those reported for other cultivars of peppers such as bell, 'Chooraehong' and New Mexican hot peppers (Biles et al., 1993; Gross et al., 1986). Similar ethylene rates have been reported for 'Chooraehong' hot peppers (Gross et al., 1986). Comparisons, however, must be viewed with caution because of the differences that could be present due to specific characteristics of each pepper type.

'Hungarian Wax' (Fig. 2A), and 'Sure Fire' (Fig. 2B), like 'Tabasco' and 'Chiltepin' (Fig. 1C), had a significant rise in $\mathrm{CO}_{2}$ production when fruit were turning color. However, the total amount of $\mathrm{CO}_{2}$ produced by the first two cultivars (Fig. 2A and B) was very low when compared to that produced by 'Tabasco' and 'Chiltepin' (Fig. 1C). 'Mitla' (Fig. 3) had significant increases in ethylene and $\mathrm{CO}_{2}$ production. Carbon dioxide production increased in 'Mesilla', 'Savory' and 'Mitla' when fruit were almost totally red (Fig. 2B and C and Fig. 3). 'Mesilla' and 'Habanero' also showed a slight, but not significant increase, in $\mathrm{CO}_{2}$ production in red-ripe fruit (Fig. 2B and C).

Other cultivars, showed significantly higher ethylene production when the fruit were either just changing color or almost totally red. For 'Banana Supreme' and 'Sure Fire' the increase in ethylene production was coincident with the peak in $\mathrm{CO}_{2}$ production, while for 'Mesilla', 'Mitla', and 'Savory' the increase in ethylene production occurred before the rise in $\mathrm{CO}_{2}$ production. Because of the selection of fruit based on color, their physiological age could be different and conclusions regarding climacteric patterns of ethylene and $\mathrm{CO}_{2}$ production, difficult to establish (Howard and Yamaguchi, 1957). However, a significant, climacteric-like peak in $\mathrm{CO}_{2}$ produc- tion appears to be present in some of the cultivars studied: 'Hungarian Wax', 'Sure Fire', 'Mesilla', 'Mitla', 'Savory', 'Tabasco' and 'Chiltepin'. As little as $0.1 \mu \mathrm{L} \cdot \mathrm{L}^{-1}$ ethylene can induce a climacteric rise in oranges (Citrus sinensis L.) (Burg and Burg, 1962). The rise in ethylene can be prior to or coincident with the rise in respiration (Burg and Burg, 1962). All cultivars, except 'King Arthur' and 'Habanero', showed an increase equal or higher than $0.1 \mu \mathrm{L} \cdot \mathrm{kg}^{-1} \cdot \mathrm{h}^{-1}$, in ethylene production when fruit were changing color or almost totally red, compared with later maturity stages. This rise was prior to or coincident to the rise in $\mathrm{CO}_{2}$ production observed in 'Sure Fire', 'Mesilla', 'Mitla', 'Savory', 'Tabasco', and 'Chiltepin'. Ethylene seems to be produced in amounts high enough to induce physiological changes in some of the studied cultivars.

For the commercial market, bell, jalapeno and cherry peppers can be harvested at the mature-green or red-ripe stage. 'Chiltepin', 'Tabasco', 'Habanero', 'Savory', 'Mesilla', 'Sure Fire', 'Banana Supreme', 'Cubanelle', and 'Hungarian Wax' are usually harvested once the fruit have turned red or at least once the color changes have initiated. Despite differences in age between fruit from different cultivars, we considered it worthwhile to compare ethylene and $\mathrm{CO}_{2}$ production of pepper cultivars at the maturity stage corresponding to horticultural maturity. Thus, comparisons between cultivars for the mature-green and red (almost completely red fruit) stages were made.

Means separation for the variables ethylene and $\mathrm{CO}_{2}$ production of each cultivar at the above mentioned maturity stages are presented in Table 2. At the mature-green stage, 'Chiltepin' and 'Tabasco' had the highest respiration rates, while 'Mitla', 'King Arthur' and 'Hungarian Wax' had the lowest. Respiration rates of mature-red peppers were between 45.2 and $291.7 \mathrm{mg} \cdot \mathrm{kg}^{-1} \cdot \mathrm{h}^{-1}$. 'Chiltepin' had the highest respiration rate. 'Camelot' had the lowest rate at the mature-red stage, along with the lowest amount of ethylene $\left(0.092 \mu \mathrm{L} \cdot \mathrm{kg}^{-1} \cdot \mathrm{h}^{-1}\right)$. Fruit of 'King Arthur' at the mature red stage had very low respiration rates, opposite to ethylene production, that was the highest.

There are several botanical differences between C. annuиm var. annum (cherry, bell, cuban, banana and jalapeno types, among others), C. annuum var. glabrisculum ('Chiltepin'), and C.frutescens ('Tabasco'). Fruit abscission occurs at the pedicel-stem insertion

Table 2. Ethylene and $\mathrm{CO}_{2}$ production in ripening fruit of selected cultivars of pepper at two maturity stages.

\begin{tabular}{|c|c|c|c|c|}
\hline \multirow[b]{3}{*}{ Cultivar } & \multicolumn{4}{|c|}{ Maturity stage } \\
\hline & \multicolumn{2}{|c|}{ Mature green } & \multicolumn{2}{|c|}{ Mature red } \\
\hline & $\begin{array}{c}\mathrm{CO}_{2} \\
\left(\mathrm{mg} \cdot \mathrm{kg}^{-1} \cdot \mathrm{h}^{-1}\right)\end{array}$ & $\begin{array}{c}\text { Ethylene } \\
\left(\mu \mathrm{L} \cdot \mathrm{kg}^{-1} \cdot \mathrm{h}^{-1}\right)\end{array}$ & $\begin{array}{c}\mathrm{CO}_{2} \\
\left(\mathrm{mg} \cdot \mathrm{kg}^{-1} \cdot \mathrm{h}^{-1}\right)\end{array}$ & $\begin{array}{c}\text { Ethylene } \\
\left(\mu \mathrm{L} \cdot \mathrm{kg}^{-1} \cdot \mathrm{h}^{-1}\right)\end{array}$ \\
\hline & \multicolumn{4}{|c|}{ Field experiment } \\
\hline Cherry Bomb & $156.4 \mathrm{~b}^{\mathrm{z}}$ & $0.219 \mathrm{~cd}$ & $67.5 \mathrm{e}$ & $0.414 \mathrm{c}$ \\
\hline King Arthur & $57.3 \mathrm{ef}$ & $0.108 \mathrm{~d}$ & $48.2 \mathrm{f}$ & $0.926 \mathrm{a}$ \\
\hline Mitla & $46.1 \mathrm{f}$ & $0.006 \mathrm{~d}$ & $121.3 \mathrm{bc}$ & $0.175 \mathrm{~d}$ \\
\hline Chiltepin & $230.2 \mathrm{a}$ & $0.337 \mathrm{~b}$ & $291.7 \mathrm{a}$ & $0.110 \mathrm{~d}$ \\
\hline Mesilla & $72.8 \mathrm{e}$ & $0.011 \mathrm{~d}$ & $133.4 \mathrm{~b}$ & $0.143 \mathrm{~d}$ \\
\hline Savory & $97.4 \mathrm{~d}$ & $0.137 \mathrm{~b}$ & $111.8 \mathrm{c}$ & $0.348 \mathrm{c}$ \\
\hline Habanero & $117.8 \mathrm{c}$ & $0.611 \mathrm{a}$ & $89.2 \mathrm{~d}$ & $0.367 \mathrm{c}$ \\
\hline Banana Supreme & $67.3 \mathrm{e}$ & $0.026 \mathrm{~d}$ & $65.3 \mathrm{e}$ & $0.692 \mathrm{~b}$ \\
\hline Tabasco & $234.0 \mathrm{a}$ & $0.106 \mathrm{~d}$ & $63.1 \mathrm{ef}$ & $0.611 \mathrm{bc}$ \\
\hline Sure Fire & $31.0 \mathrm{~g}$ & $0.006 \mathrm{~d}$ & $52.6 \mathrm{ef}$ & $0.495 \mathrm{c}$ \\
\hline Hungarian Wax & $51.5 \mathrm{f}$ & $0.002 \mathrm{~d}$ & $96.6 \mathrm{ef}$ & $0.100 \mathrm{~d}$ \\
\hline Cubanelle & $92.2 \mathrm{~d}$ & $0.044 \mathrm{~d}$ & $64.9 \mathrm{ef}$ & $0.093 \mathrm{~d}$ \\
\hline Camelot & $69.1 \mathrm{e}$ & $0.389 \mathrm{~b}$ & $45.1 \mathrm{f}$ & $0.092 \mathrm{~d}$ \\
\hline $\mathrm{LSD}^{\mathrm{z}}$ & 19.15 & 0.139 & 19.12 & 0.225 \\
\hline
\end{tabular}

${ }^{\mathrm{z}}$ Mean separation within columns by LSD, $P=0.05$. 
point in C. annuum and at the pedicel-receptacle insertion point in C. frutescens and C. annuum var. glabrisculum (Lang, 1989). This suggests there may be a differential abscission response. It has been reported that the deciduous character, determined by detachment of the fruit from the calyx when collected, can be observed only in some types of peppers. Large fruited cultivars do not show this trait, suggesting early selection against this characteristic (Smith, 1951). If ethylene is involved in the abscission of wild peppers, selecting against the deciduous character could also imply selection against climacteric production of ethylene and $\mathrm{CO}_{2}$ (Salveit, 1977). 'Chiltepin', which is considered a wild type (Andrews, 1995) and 'Tabasco', a relatively less domesticated one, showed higher $\mathrm{CO}_{2}$ production when compared to the domesticated types. Ethylene production was not higher.

Because of the diversity of peppers it is difficult to generalize about this genus as to whether the fruit are climacteric. Variations in ethylene production and respiration rates among cultivars could influence postharvest handling, packaging, and storage conditions. It may be good management to consider the type of pepper when designing postharvest systems.

\section{Literature Cited}

Andrews, J. 1995. Peppers: The domesticated Capsicums. Univ. Texas Press, Austin.

Biale, J.B. 1948. Respiration of citrus fruits in relation to metabolism of fungi. II. Effects of emanations of Penicillium digitatum, Sacc. on lemons at different stages of maturity. Proc. Amer. Soc. Hort. Sci. 52:187-191.

Biles, C.L., M.M. Wall, and K. Blackstone. 1993. Morphological and physiological changes during maturation of New Mexican type peppers. J. Amer. Soc. Hort. Sci. 118:476-480.

Burg, S.P. and E.A. Burg. 1962. Role of ethylene in fruit ripening. Plant Physiol. 13:265-302.

Conrad R.S. and F.J. Sundstrom. 1987. Calcium and ethephon effects on tabasco pepper leaf and fruit retention and fruit color development. J. Amer. Soc. Hort. Sci. 112:424-426.

Dainello, F.J. and R.R. Heineman. 1980. Postharvest ripening of jalapeno peppers as influenced by preharvest application of ethephon and storage duration. Texas Agr. Expt. Sta. PR-3756.

Gross, K., A.E. Watada, M.S. Kang, S.D. Kim, K.S. Kim, and S.W. Lee. 1986. Biochemical changes associated with the ripening of hot pepper fruit. Physiol. Plant. 66:31-36.
Harpster, M., W. Howie, and P. Dunsmuir. 1996. Characterization of a PCR fragment encoding 1-aminocyclopropane-1-carboxylate synthase in pepper (Capsicum annuum). J. Plant Physiol. 147:661-664.

Howard, F.D. and M. Yamaguchi. 1957. Respiration and the oxidative activity of particulate fraction from developing pepper fruits (Capsicum annuum L.). Plant Physiol. 32:418-423.

Kays, S.J. 1991. Postharvest physiology of perishable plant products. AVI, New York.

Knee, M. 1995. Do tomatoes on the plant behave as climacteric fruits? Physiol. Plant. 95:211-216.

Lang, G.A. 1989. Differential abscission and ripening responses to ethylene by tabasco pepper leaves and fruit: Protein "marker events" as probes. NATO ASI Ser., Ser. H 35:356-361.

Lockwood, D. and H.M. Vines. 1972. Red color enhancement of pimiento peppers with (2-chloroethyl)phosphonic acid. J. Amer. Soc. Hort. Sci. 97:192-197.

Lu, G., C. Yang, H. Liang, and Z. Lu. 1990. 'Changjiao' hot peppers are nonclimacteric. HortScience 25:807.

Lurie, S., and J.D. Klein. 1989. Cyanide metabolism in relation to ethylene production and cyanide insensitive respiration in climacteric and non-climacteric fruits. J. Plant Physiol. 135:518-521.

Lurie, S., B. Shapiro, and S. Ben-Yehoshua. 1986. Effects of water stress and degree of ripeness on rate of senescence of harvested bell pepper fruit. J. Amer. Soc. Hort. Sci. 111:880-885.

Osterli, P.P., R.M. Rice, and K.W. Dunster. 1975. Effect of ethephon on bell pepper fruit ripening. Calif. Agr. 29(7):3.

Pratt, H.K. and J.D. Goeschl. 1969. Physiological roles of ethylene in plants. Annu. Rev. Plant Physiol. 20:541-548.

Pretel, M.T., M. Serrano, A. Amoros, R. Riquelme, and F. Romojaro. 1995. Non-involvement of ACC and ACC oxidase activity in pepper fruit ripening. Postharvest Biol. Technol. 5:295-302.

Salveit, Jr., M.E. 1977. Carbon dioxide, ethylene and color development in ripening mature green bell peppers. J. Amer. Soc. Hort. Sci. 102:523525.

Salveit, Jr., M.E. 1993. Internal carbon dioxide and ethylene levels in ripening tomato fruit attached to or detached from the plant. Physiol. Plant. 89:204-210.

SAS Institute. 1988. SAS/STAT user's guide, release 6.03 ed. SAS Inst. Inc., Cary, N.C.

Sims, W.L., H.B. Collins, and B.L. Gledhill. 1970. Ethrel effects on fruit ripening of peppers. Calif. Agr. 24(2):4-5.

Smith, P.G. 1951. Deciduous ripe fruit character in peppers. Proc. Amer. Soc. Hort. Sci. 57:343-344.

Smith, P.G., B. Villalon, and P.L. Villa. 1987. Horticultural classification of peppers grown in the United States. HortScience 22:11-13. 